\title{
DEVELOPMENT OF NEW DOWNY MILDEW RESISTANT SUNFLOWER HYBRID
}

\author{
Shirshikar, S.P. , Ghodke, M.K., Jagtap, P.K. and Gir, S.N.
}

Oilseeds Research Station, Latur (M.S.) 413512 India

Received: October 10, 2012

Accepted: June 10, 2013

\section{SUMMARY}

Downy mildew, Plasmopara halstedii (Ferl.) Berl. \& de Toni of sunflower (Helianthus annuus L.) is a destructive disease occurring in almost all sunflower growing countries in the world except Australia. During 1988 this disease was noticed in Marathwada region of Maharashtra State, India for the first time and its spread is now being reported from major sunflower growing states of India like Andhra Pradesh, Karanataka, Maharashtra, Tamilnadu and Punjab. The disease is seed and soil borne and use of chemical method can solve the problem of downy mildew, but the best way is to use resistant hybrids to combat the disease. At Oilseeds Research Station, Latur (M.S.) India, a new sunflower downy mildew resistant hybrid coined as LSFH-171 was developed and now it has been released for commercial cultivation for the benefit of the farmers in major sunflower growing states of India.

Key words: sunflower, diseases, downy mildew resistant, hybrid

\section{INTRODUCTION}

Sunflower (Helianthus annuus L.) is an important oilseed crop grown in India. It is cultivated on an area of 8.97 lakh ha with 6.24 lakh metric tons of production (Anonymous, 2012). However, the average productivity is very low i.e. $696 \mathrm{~kg} / \mathrm{ha}$. Diseases are the main limiting factor in production of sunflower and they cause poor realization of genetic yield potential of sunflower hybrids (Jocić et al., 2010). More than 30 diseases have been reported worldwide on sunflower (Gulya et al., 1994). Amongst these, downy mildew disease caused by the fungus Plasmopara halstedii (Farl.) Berl. \& de Toni is an economically significant disease. This is the most destructive disease and widely spread through the seeds in all sunflower growing countries except Australia (Leepik, 1966; Viranyi, 1990). The disease being seed and soil borne in nature, it is very difficult to combat. Under Indian conditions, the sunflower crop was free from downy mildew until 1985. However, Ramnath et al. (1981) detected the presence of downy mildew oospores on sunflower

* Corresponding author: Phone:+919890069469; e-mail: spshirshikar@gmail.com 
seeds imported from Bulgaria. However first field appearance of downy mildew was reported from Oilseeds Research Station, Latur situated in Marathwada region of Maharashtra state, India, where the sunflower crop is extensively grown (Mayee and Patil, 1988) and there was a set back for sunflower cultivation in the region due to this disease. A major survey conducted in Marathwada region, covering six districts, revealed downy mildew infection in farmer's field was to the tune of 36.67 percent (Shirshikar, 1997). Hence attempts were made and in order to combat the disease, seed treatment was suggested (Shirshikar, 2005) as immediate solution. But use of genetically resistant hybrids is definitely the most effective way of controlling downy mildew. Therefore downy mildew resistant breeding programme was initiated and to identify downy mildew resistance in hybrids a downy mildew sick plot was established at the Oilseeds Research Station, Latur, where large number of sunflower hybrids is being screened for identification of downy mildew resistant hybrids (Shirshikar, 2005a).

\section{MATERIAL AND METHODS}

For the development of downy mildew resistant hybrids by line $\times$ tester method, a resistant restorer parent RHA-1-1 was selected and crossed with cms-17A (female parent) which had good combining ability, was used in breeding programme. The resultant hybrid which had downy mildew resistant gene with high yield potential was then tested through all India sunflower co-ordinated programme, across the location in India. Similarly the newly developed sunflower hybrid LSFH-171 was also evaluated for downy mildew disease reaction and this new hybrid was compared with presently ruling hybrid like KBSH-1, KBSH-44 and DRSH-1. All these hybrids were sown in downy mildew sick plot developed at Oilseeds Research Station, Latur (M.S.) India, following radical inoculation test (Patil et al., 1992) .In this test, the seeds of each test hybrids and checks were kept for germination in wet blotter paper separately for three days. After attaining radical length of 3 to $4 \mathrm{~mm}$, they were inoculated with downy mildew sporangial suspension containing $2.5 \times 10^{4}$ propagules $/ \mathrm{ml}$ prepared in sterile distilled water. The inoculated seeds after incubation of 6 hours at $15^{\circ} \mathrm{C}$, were sown in the field infected with pathogen at Oilseeds Research Station, Latur (M.S.) India. After germination of test hybrids and checks, they were again sprayed with downy mildew sporangial suspension for fifteen days in order to create more disease pressure. The observations on downy mildew incidence were recorded at 30 days after sowing by counting infected seedlings and downy mildew incidence was worked out in kharif seasons for three years (2009-10 to 2011-12). Finally all test hybrids were evaluated by the rating scale developed by Mayee and Datar (1986). Thus the downy mildew observations were recorded at Oilseeds Research Station, Latur (M.S.) India in the field infected with pathogen i.e., sick plot condition. Similarly all the hybrids and checks 
were tested only for seed yield at 54 locations in India through All India Sunflower Coordinated Project (AICRP-sunflower).

\section{RESULTS AND DISCUSSION}

The new sunflower hybrid coined as LSFH-171 was tested for three years i.e. from 2009-10 to 2011-12 at 54 locations through Coordinated Project on all India basis to find out the stability and seed yield potential of this new hybrid. The data indicated that this hybrid recorded highest seed yield over presently sunflower hybrids released for commercial cultivation in the country (Table 1). The newly developed sunflower hybrid LSFH-171 was tested in initial hybrid trial (IHT) at 20 locations during 2009-10. In second years (2010-11) it was promoted to advance hybrid trial stage I (AHT-I) and was tested at 19 locations and in third year (201112). It was again tested in advance hybrid trial stage-II (AHT-II) at 15 locations. Thus this hybrid was tested at 54 locations in three years (2009-10 to 2011-12) and it was found that this hybrid recorded highest seed yield of $1918 \mathrm{~kg} / \mathrm{ha}$ and ranked first over ruling hybrids like KBSH-1 (1612 kg/ha), KBSH-44 (1698 kg/ha) and DRSH-1 (1577 kg/ha).

Table 1: Yield performance of newly developed downy mildew resistant hybrid LSFH-171 in All India Coordinated programme (2009-10 to 2011-12)

\begin{tabular}{|c|c|c|c|c|c|c|c|}
\hline \multirow{2}{*}{$\begin{array}{l}\text { Sr. } \\
\text { No. }\end{array}$} & \multirow{2}{*}{ Trial name } & \multirow{2}{*}{$\begin{array}{c}\text { Testing } \\
\text { year }\end{array}$} & \multirow{2}{*}{$\begin{array}{c}\text { No. of } \\
\text { locations }\end{array}$} & \multicolumn{4}{|c|}{ Mean seed yield (kg/ha) } \\
\hline & & & & LSFH-171 & KBSH-1 & $\mathrm{KBSH}-44$ & DRSH-1 \\
\hline 1 & Initial hybrid trial $(\mathrm{IHT})$ & $2009-10$ & 20 & 1750 & 1510 & 1634 & 1513 \\
\hline 2 & Advance hybrid trial stage-I (AHT-I) & $2010-11$ & 19 & 1766 & 1355 & 1485 & 1302 \\
\hline 3 & Advance hybrid trial stage-II (AHT-II) & $2011-12$ & 15 & 2338 & 2076 & 2054 & 2011 \\
\hline 4 & Weighted mean & & & 1918 & 1612 & 1698 & 1577 \\
\hline 5 & Percent increase over checks & & & -- & 18.98 & 12.95 & 21.62 \\
\hline
\end{tabular}

It is evident from Table-1 that the new sunflower hybrid LSFH-171 recorded $18.98,12.95$ and 21.62 percent higher seed yield over national checks viz. KBSH$1, \mathrm{KBSH}-44$ and DRSH-1 respectively, indicating its superiority in case of seed yield over check. With regards to oil yield this new hybrid recorded highest oil yield of $694 \mathrm{~kg} / \mathrm{ha}$ (Table 2).

Table 2: Oil yield performance of new sunflower hybrid LSFH-171 in All India Coordinated programme (2009-10 to 2011-12)

\begin{tabular}{llcccccc}
\hline Sr. & \multirow{2}{*}{$\begin{array}{l}\text { Trial name } \\
\text { No. }\end{array}$} & \multirow{2}{*}{$\begin{array}{c}\text { Testing } \\
\text { year }\end{array}$} & $\begin{array}{c}\text { No of } \\
\text { location }\end{array}$ & \multicolumn{3}{c}{ Mean seed yield (kg/ha) } \\
\cline { 4 - 8 } & Initial hybrid trial (IHT) & $2009-10$ & 20 & 609 & 585 & 583 & 602 \\
2 & Advance hybrid trial stage-I (AHT-I) & $2010-11$ & 19 & 590 & 497 & 493 & 490 \\
3 & Advance hybrid trial stage-II (AHT-II) & $2011-12$ & 15 & 779 & 738 & 805 & 817 \\
4 & Mean & & & 694 & 597 & 613 & 623 \\
5 & Percent increase over checks & & & -- & 8.71 & 5.87 & 4.17 \\
\hline
\end{tabular}


The data presented in Table 2 indicated that the new hybrid recorded 8.71, 5.87 and 4.17 percent higher oil yield over KBSH-1, KBSH-44 and DRSH-1 hybrids respectively, indicating its superiority over presently ruling hybrids.

Thus the new hybrid LSFH-171 showed superiority in case of seed and oil yield over the checks on national basis with regards to downy mildew disease reaction. The new hybrid LSFH-171 was screened along with presently ruling hybrids to find out the downy mildew reaction for three years under sick plot condition. The downy mildew disease reaction data is presented in Table 3.

Table 3: Downy mildew disease reaction (\%) of new sunflower hybrid LSFH-171

\begin{tabular}{lccccc}
\hline \multirow{2}{*}{$\begin{array}{l}\text { Sr. } \\
\text { No. }\end{array}$} & Testing year & \multicolumn{4}{c}{ Name of hybrid } \\
\cline { 3 - 6 } & & LSFH-171 & KBSH-1 & KBSH-44 & DRSH-1 \\
\cline { 2 - 6 } & $2009-10$ & 0.0 & $\%$ & $\%$ & $\%$ \\
\hline 1 & $2010-11$ & 0.0 & 84.0 & 77.3 & 48.2 \\
3 & $2011-12$ & 0.0 & 40.0 & 70.0 & 95.2 \\
4 & Mean & 0.0 & 49.3 & 53.1 & 80.3 \\
\hline
\end{tabular}

The data presented in Table 3 indicated that the new sunflower hybrid LSFH171 recorded consistent resistant reaction for downy mildew disease when tested under downy mildew sick plot condition for three years. However, the compared hybrids viz. KBSH-1, KBSH-44 and DRSH-1 recorded susceptible reaction by recording 49.3, 66.8 and 74.5 percent disease reaction respectively indicating its susceptibility to downy mildew disease. Thus new sunflower hybrid LSFH-171 recorded highest seed and oil yield as well as it had recorded resistant reaction for downy mildew disease.

Looking in to the downy mildew disease resistance and superiority in case of seed and oil yield, this hybrid was identified for commercial cultivation by Indian Council of Agricultural Research (ICAR) during Annual Group Meeting of sunflower workers held at University Of Agriculture Sciences (UAS) Bengaluru, India during 26-28 April, 2012 (Anonymous, 2012a) for Zone-II comprising three major sunflower growing state viz. Maharashtra, Tamilnadu and Andhra Pradesh of India which contributes more than $80 \%$ of national acreage of sunflower cultivation.

\section{REFERENCES}

Anonymous, 2012. Project Directors Report, 2011-12. Annual Group Meeting on Sunflower held at UAS, Bengaluru (KR), India, April 26- 28, 2012.

Anonymous, 2012(a). Proceedings of Annual Group Meeting on Sunflower 2011-12, held at UAS, Bengaluru (KR), India, April 26- 28, 2012.

Gulya, T., Barlin, N. and Lamey, A., 1994. Sunflower diseases. In: "Sunflower production" Ext. Bulletin (Ed. Berglund, D.R., 1994). North Dakota Agric. Experiment Station and North Dakota State Univ. 98: 44-62.

Jocić, S., Cvejić, S., Hladni, N., Miladinović, D. and Miklič, V., 2010. Development of sunflower genotypes resistant to downy mildew. Helia 33(53): 173-180.

Leepik, E.E., 1966. Origin and specialization of Plasmopara halstedii compels of the compositae. FAO Plant. Prot. Bull. 14: 172. 
Mayee, C.D. and Datar, V.V., 1986. Phytopathometry. Technical Bulletin -1. Marathwad Agricultural University, Parabhani, pp.25.

Mayee, C.D. and Patil, M.A., 1988. Downy mildew of sunflower. Indian Phytopath. $39: 314$.

Patil, M.A., Mayee, C.D. and Phad, H.B., 1992. Sunflower downy mildew. Information Bulletin. Oilseeds Research Station, Latur (M.S.) India. Pp. 76.

Ramnath, A.K., Lambat, B.N., Mukewar and Indrarani, 1981. Interceptions of pathogenic fungi on imported seeds and planting material. Indian Phytopath. 34: 282-286.

Shirshikar, S.P., 1997. Survey of downy mildew disease of sunflower in Marathwada region. J. Maharashtra Agric. Univ. 22(1): 135-136.

Shirshikar, S.P., 2005. Control of downy mildew in sunflower with a new metalaxyl formulation Apron XL-35 E.S. Helia 28(43): 159-164.

Shirshikar, S.P., 2005a. Present status of sunflower downy mildew in India. Helia 28(43): 153158.

Viranyi, F; 1990. Downy mildew of sunflower. In: Plant Diseases of International Importance (Eds. Chuge et al., 1980). Prentice Hall, Inglewood Cliff, New Jersey. 363: 328-340. 
